NOTE

\title{
Polyclonal antibodies specific for VP1 and VP3 capsid proteins of Taura syndrome virus (TSV) produced via gene cloning and expression
}

\author{
Parin Chaivisuthangkura ${ }^{1}$, Thanawan Tejangkura ${ }^{1}$, Sombat Rukpratanporn ${ }^{2}$, \\ Siwaporn Longyant ${ }^{1}$, Weerawan Sithigorngul ${ }^{1}$, Paisarn Sithigorngul ${ }^{1, *}$ \\ ${ }^{1}$ Department of Biology, Faculty of Science, Srinakharinwirot University, Bangkok 10110, Thailand \\ ${ }^{2}$ Center of Excellence for Marine Biotechnology at Chulalongkorn University, National Center for Genetic Engineering and \\ Biotechnology (BIOTEC), Bangkok 10330, Thailand
}

\begin{abstract}
Capsid protein genes VP1 and VP3 of Taura syndrome virus (TSV) were cloned into pGEX-6P-1 expression vector and transformed into Escherichia coli BL21. After induction, recombinant VP1 (rVP1) and recombinant VP3 (rVP3) were produced, purified by SDS-PAGE and used for immunization of Swiss mice for antisera production. Anti-rVP1 and anti-rVP3 antisera showed specific immunoreactivities to rVP1 and rVP3 proteins, respectively, by Western blot assay and also yielded good results for detection of TSV in various shrimp tissues by immunohistochemistry. This is the first step towards our target of preparing monoclonal antibodies specific to rVP1 and rVP3 for use in simple immuno-diagnostic test kits for TSV detection and identification.
\end{abstract}

KEY WORDS: Immunohistochemistry · Litopenaeus vannamei · Polyclonal antibody · VP1 · VP3 · Western blot $\cdot$ Taura syndrome virus $\cdot$ TSV

Resale or republication not permitted without written consent of the publisher

\section{INTRODUCTION}

Taura syndrome virus (TSV) is a major viral pathogen first described in cultured white shrimp Litopenaeus vannamei (also called Penaeus vannamei) in the western hemisphere (Hasson et al. 1995, 1999, Lightner et al. 1995, Bonami et al. 1997, Lotz, 1997, Overstreet et al. 1997). Subsequently, epizootics have been observed in Taiwan in 1998 (Tu et al. 1999) and more recently in Thailand (Nielsen et al. 2005), after introduction of $L$. vannamei from the Americas for aquaculture. Detection of TSV infection is often based on RT-PCR and in situ hybridization methods (Mari et al. 1998, Nunan et al. 1998), as well as quantitative real-time RT-PCR (Dhar et al. 2002, Mouillesseaux et al. 2003, Nunan et al. 2004, Tang et al. 2004). Since disease caused by TSV is widespread, screening large numbers of shrimp is essential to prevent TSV introduction into aquaculture ponds at stocking and to monitor for its presence during cultivation. Specific detection by immunoassay is an alternative choice for low cost screening of large numbers of samples. Chicken and mouse polyclonal antisera and monoclonal antibodies against TSV have been produced using purified viral antigens (Poulos et al. 1999) and these have been used to develop Western blot, dot blot and immunohistochemical assays for detection of various TSV strains (Erickson et al. 2002). Since the complete genome sequence of TSV is now known (Mari et al. 2002), it is now possible to produce unlimited quantities of recombinant viral structural proteins as antigens. This eliminates the need for the rather laborious and time-consuming processes required to purify virus in order to obtain antigens for production of polyclonal and monoclonal antibodies. This work describes the expression of VP1 and VP3 genes to produce VP1 and VP3 proteins, and the production of specific polyclonal antibodies for detection of TSV. 
This is the first step in achieving the ultimate goal of developing simple detection kits based on monoclonal antibodies.

\section{MATERIALS AND METHODS}

Viral preparation. Natural Taura syndrome virus (TSV) infected Litopenaeus vannamei were obtained from a farm at Chantaburi province, Thailand and from Centex Shrimp, Faculty of Science, Mahidol University, Thailand. Gills from infected shrimp were homogenized in 2X PBS (phosphate buffered saline, $\mathrm{pH}$ 7.2), centrifuged at $3000 \times g$ for $30 \mathrm{~min}$ and aliquots of the supernatant were stored at $-70^{\circ} \mathrm{C}$.

TSV RNA preparation. Gills from naturally TSVinfected Litopenaeus vannamei were homogenized in lysis buffer (50 mM Tris-HCl, pH 9, 100 mM EDTA, $50 \mathrm{mM} \mathrm{NaCl}, 2 \% \mathrm{SDS}_{\text {; }} \mathrm{T}$. W. Flegel pers. comm.) and RNA was extracted from $200 \mu$ l of homogenate using a High Pure viral nucleic acid kit (Roche Molecular Biochemicals) as described in the product manual.

Cloning and expression of VP1 and VP3. TSVinfected shrimp RNA was used as the template for cDNA synthesis using Superscript III reverse transcriptase (Invitrogen), oligo(dT) and Escherichia coli RNase $\mathrm{H}$. Polymerase chain reaction (PCR) was used with this cDNA as template, $P f_{X}$ polymerase (Invitrogen) and primers TSVF (5'-CG GGATCC TCA AAA GAT AGG GAT ATG AC-3') and TSVREco (5'-G GAATTC ATG TGT GGA TGG ATA TAT AC-3') containing added restriction sites (underlined) to amplifiy the VP1 gene or primers VP3F (5'-CG GGATCC GCT GGT CTG GAC TAC TCC AG-3') and VP3R (5'-CG GAATTC TTA AGC CAA TTC GGC AGG TC-3') with added restriction sites (underlined) to amplify the VP3 gene. Each PCR product was cloned into BamHI and EcoRI sites of the pGEX-6P-1 expression vector and transformed into $E$. coli strain BL21. The integrity of the open reading frame of each recombinant plasmid was verified by DNA sequencing.

Preparation of recombinant VP1 and VP3 proteins. Escherichia coli with each recombinant plasmid was cultured in Luria-Bertani (LB) broth to exponential phase, and expression of the recombinant proteins was induced with $1 \mathrm{mM}$ isopropyl- $\beta$-D-thiogalacto-pyranoside (IPTG) for $4 \mathrm{~h}$. After centrifugation at $4000 \times g$ for $20 \mathrm{~min}$ for each recombinant, the bacterial pellet was dissolved in $100 \mathrm{mM} \mathrm{NaH} \mathrm{PO}_{4}, 10 \mathrm{mM}$ Tris- $\mathrm{HCl}$, $8 \mathrm{M}$ urea pH8, containing $1 \mathrm{mM}$ phenylmethylsulfonyl fluoride (PMSF) and sonicated until a clear lysate was obtained. The lysate was separated by $12 \%$ SDSPAGE. After staining with Coomassie brilliant blue, the recombinant protein bands were cut out, destained, collected in dialysis bags, and the protein was eluted with a transblot apparatus (BioRad) at $70 \mathrm{~V}$ for $6 \mathrm{~h}$. The protein solution was dialyzed to eliminate SDS and salt before determining the protein content by Bradford protein assay (Bradford 1976). The protein solution was divided into small aliquots and stored at $-70^{\circ} \mathrm{C}$.

Polyclonal antibody production. For each recombinant protein, 3 Swiss mice were injected intra-peritoneally with $0.05 \mathrm{mg}$ protein per mouse mixed with complete Freund's adjuvant in a 1:1 ratio. Mice were subsequently injected 3 more times at 2 -weekly intervals with the protein mixed with incomplete Freund's adjuvant. One week after the 4 th injection, mouse antisera were collected and tested against Escherichia coli lysate and purified recombinant proteins by Western blot. The antibodies were also evaluated by immunohistochemistry using head tissues from TSV infected Litopenaeus vannamei.

Western blot analysis. Lysates of Escherichia coli BL21 with pGEX-6P-1 plasmid, E. coli with VP1-pGEX plasmid, E. coli with VP3-pGEX plasmid, purified recombinant (rVP1) and purified rVP3 were separated by $12 \%$ SDS-PAGE according to the method described by Laemmli (1970). Samples were electrophoresed for $6 \mathrm{~h}$ at $30 \mathrm{~V}$ and gels were stained using Coomassie brilliant blue. For Western blot analysis, samples resolved by SDS-PAGE were electroblotted onto nitrocellulose membranes using a Transblot apparatus (BioRad) then

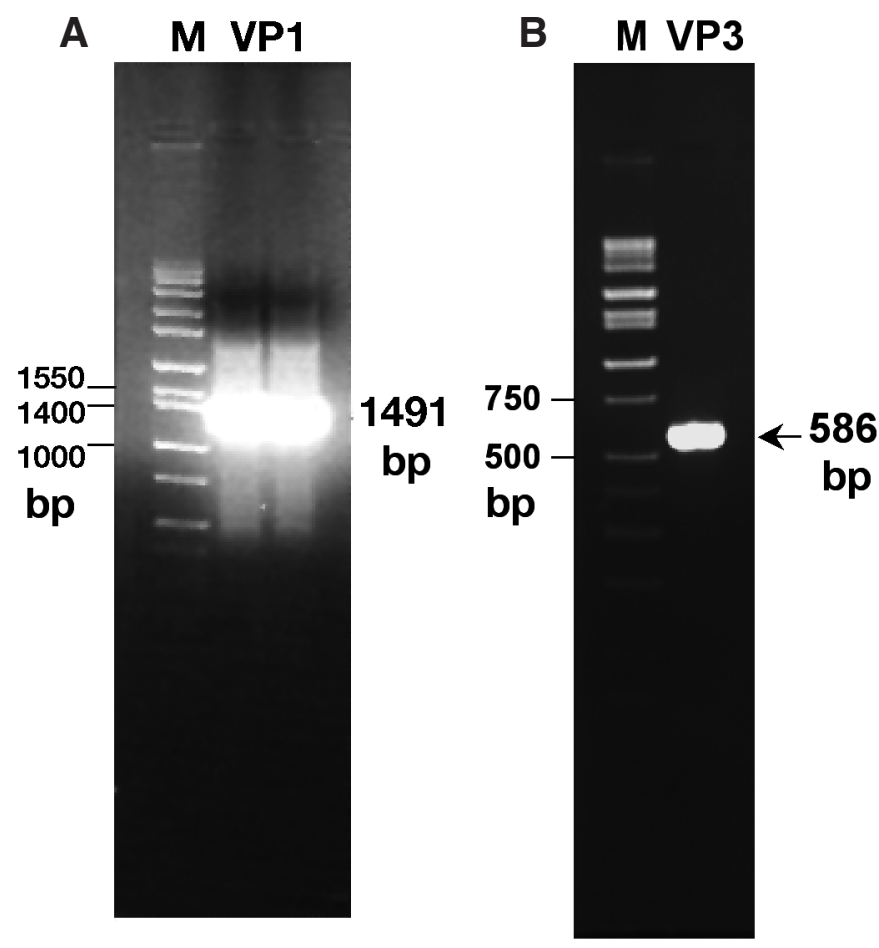

Fig. 1. Ethidium bromide stained gels of (A) VP1 and (B) VP3 PCR products. $\mathrm{M}=\mathrm{DNA}$ marker 


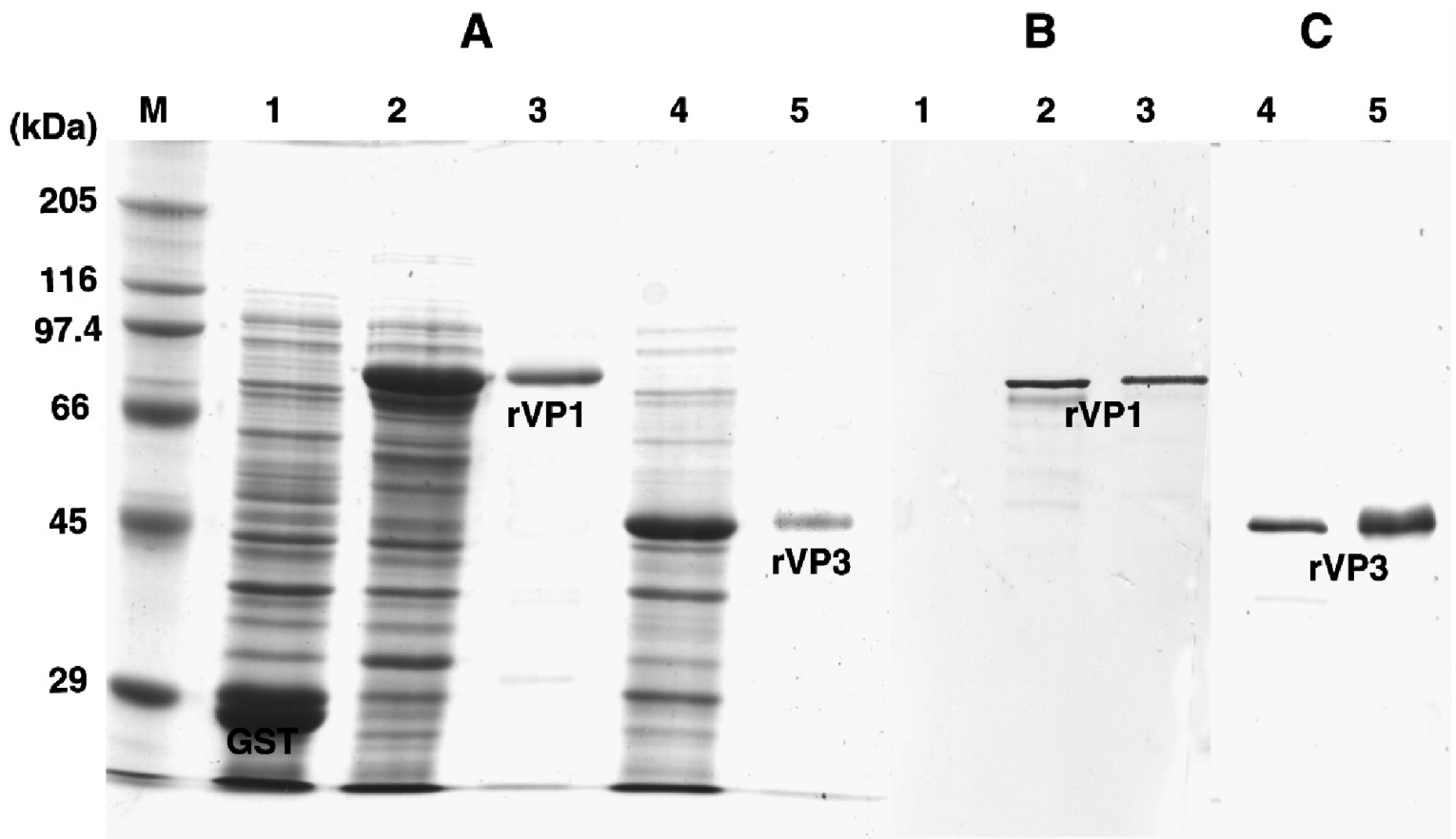

Fig. 2. SDS-PAGE and Western blot analyses. (A) Coomassie blue stained gel, (B) Western blot using polyclonal antibodies against rVP1 and (C) rVP3. M = protein marker, 1 = lysate of Escherichia. coli strain BL21 containing pGEX-6P-1 (GST = $26 \mathrm{kDa}$ ), $2=$ lysate of $E$. coli strain BL21 containing VP1-pGEX plasmid $(\mathrm{rVP} 1=80 \mathrm{kDa}), 3=$ purified rVP1, $4=$ lysate of $E$. coli strain BL21 containing VP3-pGEX plasmid (rVP3 $=50 \mathrm{kDa}), 5=$ purified rVP3

incubated for $4 \mathrm{~h}$ with either mouse anti-rVP1 or antirVP3 antiserum, preabsorbed with the expressed lysate of E. coli harboring pGEX-6P-1 plasmid, at a dilution of $1: 3000$ in $5 \%$ Blotto (5\% nonfat dry milk, $0.1 \%$ Triton X-100 in PBS). After extensive washing in $0.5 \%$ Blotto, the membrane was incubated in horseradish peroxidase conjugated goat anti-mouse IgG heavy- and light-chain specific antibody (GAM-HRP; BioRad) at 1: 1000 in 5\% Blotto for $4 \mathrm{~h}$. The membranes were then washed extensively, as above, and incubated for $5 \mathrm{~min}$ in a substrate mixture containing $0.006 \%$ hydrogen peroxide, $0.03 \%$ diaminobenzidine (DAB), $0.05 \%$ cobalt chloride in PBS and washed extensively in distilled water.

Immunohistochemistry. Cephalothoraces from TSVinfected Litopenaeus vannamei were removed and fixed in Davidson's fixative solution for $24 \mathrm{~h}$ before processing for paraffin sectioning. Serial sections $(8 \mu \mathrm{m}$ thickness) were prepared and processed for indirect immunoperoxidase staining using either mouse antirVP1 or anti-rVP3 antiserum at a dilution of 1:1000 and GAM-HRP at a dilution of 1:1000 in 10\% calf serum in PBS for $5 \mathrm{~h}$ at $37^{\circ} \mathrm{C}$ for each step. After extensive washing with PBS, peroxidase activity was revealed by incubation with $0.03 \% \mathrm{DAB}, 0.006 \%$ hydrogen peroxide in PBS for $5 \mathrm{~min}$. Preparations were counterstained with haematoxylin and eosinY, dehydrated in a graded ethanol series, cleared in xylene and mounted in Permount (Sithigorngul et al. 2002).

\section{RESULTS AND DISCUSSION}

Amplicons of VP1 (1491 bp) and VP3 (586 bp) were obtained by PCR (Fig. 1). After transformation into Escherichia coli and induction, rVP1 and rVP3 proteins were visualized by Coomassie blue staining as bands of GST-tagged VP1 with a molecular mass of $80 \mathrm{kDa}$ (Fig. 2A, Lane 2) and GST-tagged VP3 with a molecular mass of $50 \mathrm{kDa}$ (Fig. 2A, Lane 4). After the recombinant bands were cut from the gel and eluted, high purity rVP1 and rVP3 were obtained (Fig. 2A, Lanes 3 and 5). The protein was adjusted to $1 \mathrm{mg} \mathrm{ml}^{-1}$ protein before storage of small aliquots at $-70^{\circ} \mathrm{C}$.

After immunization, antisera from 3 mice displayed relatively strong immunoreactivity and specificity by Western blot against rVP1 (80 kDa: Fig. 2B, Lanes 2 and 3) and rVP3 (50 kDa: Fig. 2B, Lanes 4 and 5). Since the antisera obtained were completely preabsorbed with expressed lysate of Escherichia coli harboring pGEX6P-1 plasmid, no immunoreactivity against GST at $26 \mathrm{kDa}$ was observed (Fig. 2B, Lane 1). Using the same anti-rVP1 and anti-rVP3 antisera for immunohistochemistry, specific reactions were observed in various organs including the subcuticular epithelium (Fig. 3, Panels A1 and B1), haemolymph vessels (Fig. 3, Panels A2 and B2) and lymphoid organs (Fig. 3, Panels A3 and B3) of TSVinfected Litopenaeus vannamei. However, no immunoreactivity was observed in tissues with uninfected shrimp tissues or tissues from shrimp infected with white 
A
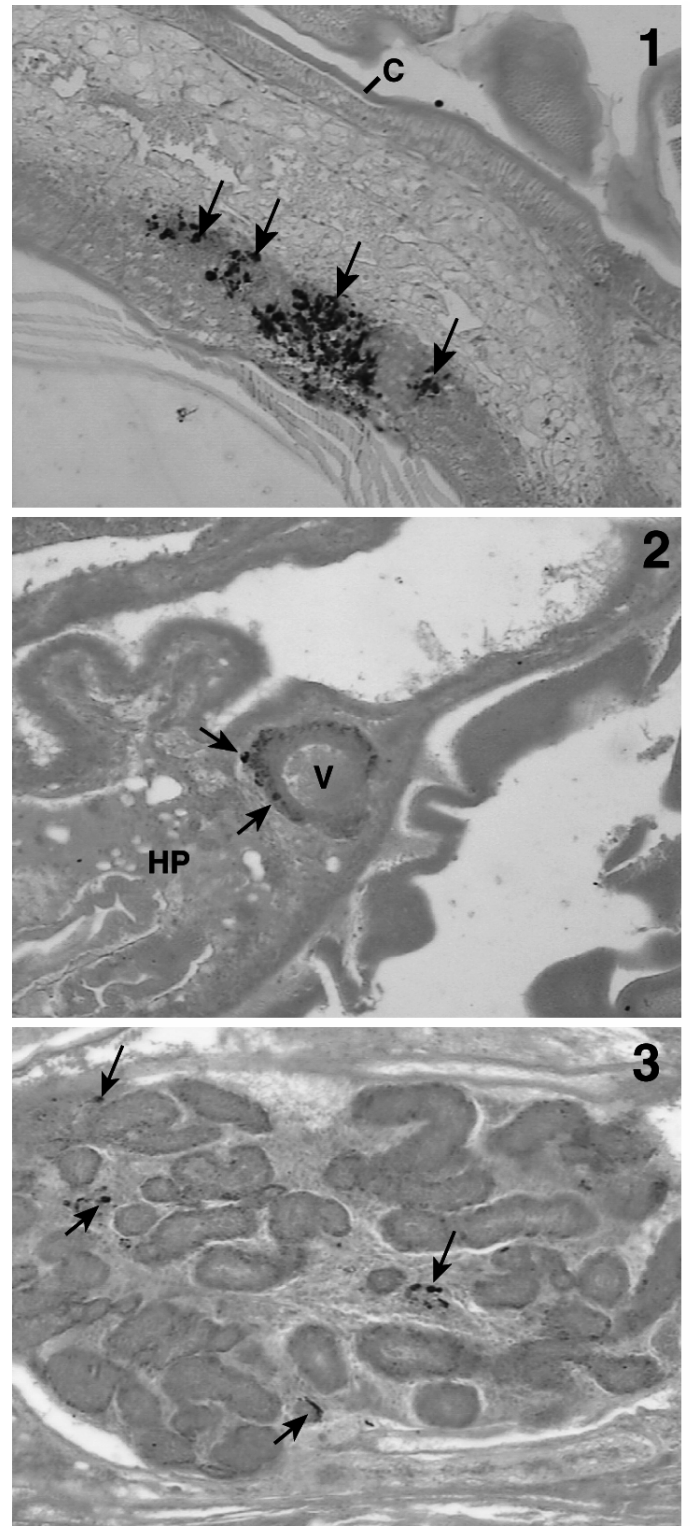

B
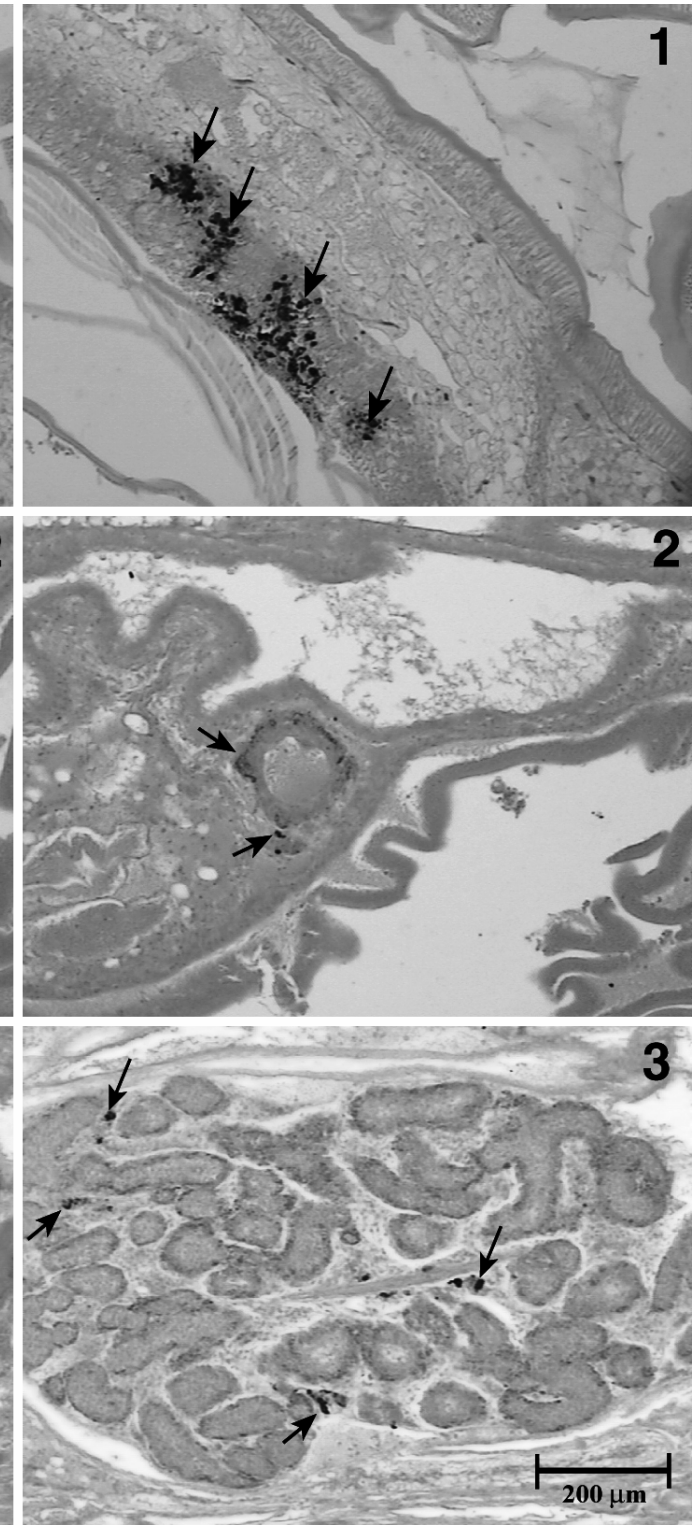

Fig. 3. Immunohistochemistry of TSV-infected shrimp: 2 consecutive sections treated with (A) mouse anti-rVP1 polyclonal antibody and (B) mouse anti-rVP3 polyclonal antibody at 1:1000 dilution before counterstaining with Eosin Y. Immunoreactivities of anti-rVP1 and anti-rVP3 antibodies occurred at similar positions in all organs: (1) subcuticular epithelium of mouth appendage,

(2) haemolymph vessel (V) to hepatopancreas and (3) lymphoid organ

spot syndrome (WSSV), yellow-head virus (YHV), or hepatopancreatic parvovirus (HPV) (not shown). This result confirmed that the recombinant proteins demonstrated immunoreactivity similar to natural proteins of TSV. In contrast, some monoclonal antibodies reported previously for TSV demonstrated cross reactivity to haemolymph from shrimps infected with infectious hypodermal and hematopoietic necrosis virus (IHHNV), YHV and WSSV (Poulos et al. 1999).

The results presented here indicate that these mice would be useful for monoclonal antibody production specific to TSV, similar to previous studies with WSSV
rVP28 protein (Lui et al. 2002, Chaivisuthangkura et al. 2004). However, monoclonal antibodies against various epitopes of the antigen should be selected since a single monoclonal antibody may not be able to detect all TSV isolates from different geographic areas (Erickson et al. 2002, Robles-Sikisaka et al. 2002). Recent study revealed that monoclonal antibody $1 \mathrm{~A} 1$, specific to the VP1 region, did not react with a new variant, Belize isolate (BLZ02TSV) by Western blot analysis and immunohistochemistry, suggestive of changes in the VP1 region of the TSV genome (Erickson et al. 2005, Tang \& Lightner 2005). 
In addition to use in the production of polyclonal and monoclonal antibodies, the recombinant proteins rVP1 and rVP3 may have potential as protective agents against TSV infection, as has been shown using recombinant envelope proteins of WSSV (Witteveldt et al. $2004 a, b)$.

Acknowledgements. This work was supported by a grant from the National Center for Genetic Engineering and Biotechnology, Thailand to P.C. We express our appreciation to Prof. Dr. Timothy Flegel and Miss Linda Nielson from CENTEX Shrimp, Thailand, for kindly providing an RNA extract from Litopenaeus vannamei infected with TSV, and Mrs. Koolvara Sangrungruang from Kung Krabaen Bay Fisheries development Study Center, Chantaburi, Thailand, for providing $L$. vannamei infected with TSV.

\section{LITERATURE CITED}

Bonami JR, Hasson KW, Mari J, Poulos BT, Lightner DV (1997) Taura syndrome of marine penaeid shrimp: characterization of the viral agent. J Gen Virol 78:313-319

Bradford MM (1976) A rapid and sensitive method for the quantification of microgram quantities of protein utilizing the principle of protein-dye binding. Anal Biochem 72: 248-254

Chaivisuthangkura P, Tangkhabuanbutra J, Longyant S, Sithigorngul W, Rukpratanporn S, Menasvata P, Sithigorngul P (2004) Monoclonal antibodies against a truncated viral envelope protein (VP28) can detect white spot syndrome virus (WSSV) infections in shrimp. ScienceAsia 30: 359-363

Dhar AK, Roux MM, Klimpel KR (2002) Quantitative assay for measuring the Taura syndrome virus and yellow head virus load in shrimp by real-time RT-PCR using SYBR Green chemistry. J Virol Methods 104:69-82

Erickson HS, Zarain-Herzberg M, Lightner DV (2002) Detection of Taura syndrome virus (TSV) strain differences using selected dianostic methods: diagnostic implications in penaeid shrimp. Dis Aquat Org 52:1-10

Erickson HS, Poulos BT, Tang KFJ, Bradley-Dunlop D, Lightner DV (2005) Taura syndrome virus from Belize represents a unique variant. Dis Aquat Org 64:91-98

Hasson KW, Lightner DV, Poulos BT, Redman RM, White BL, Brock JA, Bonami JR (1995) Taura syndrome in Penaeus vannamei: Demonstration of a viral etiology. Dis Aquat Org 23:115-126

Hasson KW, Lightner DV, Mari J, Bonami JR, Poulos BT, Mohney LL, Redman RM, Brock JA (1999) The geographic distribution of Taura syndrome virus (TSV) in the Americas: determination by histopathology and in situ hybridization using TSV-specific cDNA probes. Aquaculture 171:13-26

Laemmli UK (1970) Cleavage of structural proteins during the assembly of the head of bacteriophage T4. Nature 227: 680-85

Lightner DV, Redman RM, Hasson KW, Pantoja CR (1995) Taura syndrome in Penaeus vannamei (Crustacea: Decapoda): gross signs, histopathology and ultrastructure. Dis Aquat Org 21:53-59

Lotz JM (1997) Effect of host size on virulence of Taura virus to the marine shrimp Penaeus vannamei (Crustacea: Penaeidae). Dis Aquat Org 30:45-51

Editorial responsibility: Timothy Flegel,

Bangkok, Thailand
Lui W, Wang YT, Tian DS, Yin ZC, Kwang J (2002) Detection of white spot syndrome virus (WSSV) of shrimp by means of monoclonal antibodies (MAbs) specific to an envelope protein (28 kDa). Dis Aquat Org 49:11-18

Mari J, Bonami JR, Lightner DV (1998) Taura syndrome of penaeid shrimp: cloning of the viral genome fragments and development of specific gene probes. Dis Aquat Org 33:11-17

Mari J, Poulos BT, Lightner DV, Bonami JR (2002) Shrimp Taura syndrome virus: genomic characterization and similarity with members of the genus Cricket paralysis-like viruses. J Gen Virol 83:915-926

Mouillesseaux KP, Klimpel KR, Dhar DK (2003) Improvement in the specificity and sensitivity of detection for the Tuara syndrome virus and yellow head virus of penaeid shrimp by increasing the amplicon size in SYBR Green real-time RT-PCR. J Virol Methods 111:121-127

Nielsen L, Sang-oum W, Cheevadhanarak S, Flegel TW (2005) Taura syndrome virus (TSV) in Thailand and its relationship to TSV in China and the Americas. Dis Aquat Org 63:101-106

Nunan LM, Poulos BT, Lightner DV (1998) Reverse transcription polymerase chain reaction (RT-PCR) used for the detection of Taura syndrome virus (TSV) in experimentally infected shrimp. Dis Aquat Org 34:87-91

Nunan LM, Tang-nelson K, Lightner DV (2004) Real-time RTPCR determination on viral copy number in Penaeus vannamei experimentally infected with Taura syndrome virus. Aquaculture 229:1-10

Overstreet RM, Lightner DV, Hasson KW, McIlwain S, Lotz JM (1997) Susceptibility to Taura syndrome virus of some penaeid shrimp species native to the gulf of Mexico and Southeastern United States. J Invertebr Pathol 69:165-176

Poulos BT, Kibler R, Bradley-Dunlop D, Mohney LL, Lightner DV (1999) Production and use of antibodies for the detection of Taura syndrome virus in penaeid shrimp. Dis Aquat Org 37:99-106

Robles-Sikisaka R, Hasson KW, Garcia DK, Brovont KE, Cleveland KD, Klimpel KR, Dhar AK (2002) Genetic variation and immunohistochemical differences among geographic isolates of Taura syndrome virus of penaeid shrimp. J Gen Virol 83:3123-3130

Sithigorngul $\mathrm{P}$, Rukpratanporn S, Longyant S, Chaivisuthangkura P, Sithigorngul W, Menasveta P (2002) Monoclonal antibodies specific to yellow-head virus (YHV) of Penaeus monodon. Dis Aquat Org 49:71-76

Tang KFJ, Lightner DV (2005) Phylogenetic analysis of Taura syndrome virus isolates collected between 1993-2004 and virulence comparison between two isolates representing different genetic variants. Virus Res 112:69-76

Tang KFJ, Wang J, Lightner DV (2004) Quantitation of Taura syndrome virus by real-time RT-PCR with TaqMan assay. J Virol Methods 11:109-114

Tu C, Haung HT, Chuang SH, Hsu JP and 5 others (1999) Taura syndrome in Pacific white shrimp Penaeus vannamei cultured in Taiwan. Dis Aquat Org 38:159-161

Witteveldt J, Vlak JM, van Hulten MCV (2004a) Protection of Penaeus monodon against white spot syndrome virus using a WSSV subunit vaccine. Fish Shellfish Immunol 16: 571-579

Witteveldt J, Cifuentes CC, Vlak JM, van Hulten MCV (2004b) Protection of Penaeus monodon against white spot syndrome virus by oral vaccination. J Virol 78: 2057-2061

Submitted: August 18, 2005; Accepted: December 1, 2005

Proofs received from author(s): February 24, 2006 